\title{
Inhibition of matrix-induced bone differentiation by advanced glycation end-products in rats
}

\author{
Y. Fong ${ }^{1}$, D. Edelstein ${ }^{2}$, E.A. Wang ${ }^{3}$, M. Brownlee ${ }^{2}$ \\ ${ }^{1}$ Department of Surgery, Memorial Sloan-Kettering Cancer Center, New York, New York, USA \\ ${ }^{2}$ Diabetes Research Center, Albert Einstein College of Medicine, Bronx, New York, USA \\ ${ }^{3}$ Developmental Biology, Genetics Institute, Inc., Cambridge, Massachusetts, USA
}

\begin{abstract}
Summary. Glycation of long-lived proteins is an inevitable consequence of aging that is accelerated in patients with diabetes mellitus. Treatment of demineralized bone matrix particles from 35-week-old normal Long-Evans rats with glycolaldehyde, a precursor of advanced glycation end-products, was used to assess the effects of bone-matrix glycation on the process of bone differentiation. Matrix was incubated in phosphate buffered saline alone, phosphate buffered saline containing glycolaldehyde, glycolaldehyde plus the advanced glycation product-inhibitor aminoguanidine, or glycolaldehyde plus the advanced glycation product-inhibitor sodium cyanoborohydride. Glycolaldehyde increased the matrix advanced glycation product content as measured by specific fluorescence more than two-fold, while inhibiting bone differentiation more than $90 \%$ as measured by in vivo ${ }^{45} \mathrm{CaCl}_{2}$ uptake, alkaline phosphatase levels, and histology. In contrast, simultaneous incubation with the advanced glyca-
\end{abstract}

tion product-inhibitor aminoguanidine or sodium cyanoborohydride not only reduced fluorescence to normal, but also restored bone differentiation. Furthermore, the inhibition of bone differentiation by glycolaldehyde was not reversed by subsequent application of recombinant bone morphogenetic protein-2. These observations suggest that formation of advanced glycation products on bone matrix alters its ability to induce bone formation, and probably involves alterations of binding sites for extractable proteins with direct bone inductive properties such as bone morphogenetic protein-2. Decreased bone formation associated with aging and diabetes may result, in part, from advanced glycation product formation on matrix proteins.

Key words: Aging, bone matrix, bone healing, bone differentiation, diabetes mellitus.
Aging and diabetes mellitus are each associated with changes in bone metabolism characterized by a loss in bone mass [1] that may lead to an increased incidence of fractures and poor healing of fractures [1-5]. The reason for such bone loss in old age is clearly multifactorial. Hormonal, mechanical, and nutritional mechanisms [1] can result both in defects of bone formation as well as increased bone resorption $[1,6,7]$. The clinical bone loss [8] seen in diabetes is also associated with defects in bone formation $[9,10]$ and increased osteolysis $[11,12]$. Proposed mechanisms for these changes in diabetic patients have also included nutritional, hormonal, and vascular factors [13]. However, little experimental support for any proposed mechanism is currently available.

Cross-linking of long-lived proteins such as collagen increases as a function of age. This process of protein crosslinking occurs non-enzymatically, and involves reaction of a sugar with an amino group on the protein. The reactive Amadori products that are formed can then bind with amino groups on other proteins to form advanced glyca- tion end-products (AGEs) through intermolecular crosslinks [14]. This process is greatly accelerated with diabetes $[14,15]$, and the resulting cross-linked proteins are thought to contribute to many of the complications associated with diabetes [14-16]. AGE-formation causes decreased binding of matrix components to each other, and of cells to matrix [17-20]. Since adhesion of growth factors as well as many types of cells to collagen substrates in bone matrix is essential for growth and proliferation of bone [21], we postulated that such glycation of the collagenous matrix of bone may result in impaired adhesion of growth factors or osteogenic cells and lead to changes in structure and healing in diabetic bones. In the present study, the hypothesis that matrix glycation alters bone metabolism was tested in a well-established experimental model of demineralized bone-matrix-induced endochondral bone formation [22-24]. 


\section{Materials and methods}

\section{Animals}

The experimental protocol was reviewed and approved by the Institutional Animal Care and Use Committee of the Albert Einstein College of Medicine. Adult female rats of the Long-Evans strain were used for matrix preparation, and Long-Evans rats, aged 28 35 days, were used for implantation.

\section{Bone matrix preparation}

Bone matrix was prepared from dehydrated diaphyseal shafts of rat femur and tibia. These were pulverized in a CR.C micromill (Techni Laboratories, Vineland, NJ, USA). Particles were sieved to a size of $74-420 \mu \mathrm{m}$. The particles were washed in $0.5 \mathrm{~N} \mathrm{HCl}(25 \mathrm{meq} / \mathrm{g})$ for 3 $h$, followed by repeated exchanges of water for $2 h$, then washed in ethanol for $1 \mathrm{~h}$, and finally in ethyl ether for $30 \mathrm{~min}$. The particles were dried overnight at $37^{\circ} \mathrm{C}[24]$.

\section{Implantation}

In vivo assays of bone-inductive capacity of the matrix was conducted by implanting the matrix $(10-20 \mu \mathrm{g})$ into subcutaneous pockets in the back of Long-Evans rats (28-35 days old) under general anaesthesia.

\section{Experimental protocols}

Experiment 1 was performed to determine the bone-inductive capacity of the matrix, the effects of glycolaldehyde (GA), and the ability of aminoguanidine (AG) to inhibit the effects of glycolaldehyde. Bone matrix was incubated in three ways: (1) phosphate buffered saline (PBS), (2) $50 \mathrm{mmol} / \mathrm{l} \mathrm{GA}$ in PBS (GA), and (3) $50 \mathrm{mmol} / \mathrm{l} \mathrm{GA}$ and $250 \mathrm{mmol} / 1$ aminoguanidine- $\mathrm{HCl}(\mathrm{GA}+\mathrm{AG})$. All incubations were performed for $3 \mathrm{~h}$ at $37^{\circ} \mathrm{C}$. After the incubations, a portion of each resultant matrix was assayed by fluorescence for cross-linking. Matrix from each group was also implanted for bioassay of bone inductive properties: (1) PBS $(n=28),(2) \mathrm{GA}(n=12)$, and (3) GA + AG $(n=12)$. Fourteen days later, the implants were assayed for bone induction by ${ }^{45} \mathrm{Ca}$ uptake, alkaline phosphatase content, calcium content, and histology as outlined below.

Experiment 2 was performed to determine the ability of sodium cyanoborohydride $\left(\mathrm{NaCNBH}_{3}\right)$, which chemically reduces Schiff base precursors of AGEs, to inhibit the effects of glycolaldehyde. Bone matrix was incubated in three ways: 1) PBS (PBS), 2) $50 \mathrm{mmol} / \mathrm{l} \mathrm{GA}$ in PBS (GA), and 3) $50 \mathrm{mmol} / \mathrm{l} \mathrm{GA}$ and $50 \mathrm{mmol} / \mathrm{l}$ $\mathrm{NaCNBH}_{3}\left(\mathrm{GA}+\mathrm{NaCNBH}_{3}\right)$. All incubations were performed for $3 \mathrm{~h}$ at $37^{\circ} \mathrm{C}$. After the incubations, a portion of each resultant matrix was assayed by fluorescence for cross-linking. Matrix from each group was also implanted for bio-assay of bone inductive properties: (1) PBS $(n=23)$, (2) GA $(n=7)$, and (3) GA + $\mathrm{NaCNBH}_{3}(n=12)$. Fourteen days later, the implants were assayed for bone induction by ${ }^{45} \mathrm{Ca}$ uptake, alkaline phosphatase content, calcium content, and histology as outlined below.

Experiment 3 was performed to determine if application of bone morphogenetic protein 2 (BMP-2), a potent bone-derived morphogenic cytokine, can restore bone-inductive capacity to modified matrix. Bone matrix was incubated in two ways: 1) PBS (PBS), 2) $50 \mathrm{mmol} / \mathrm{GA}$ in PBS (GA). The incubated material was combined with either $7 \mu \mathrm{g}$ or $21 \mu \mathrm{g}$ of BMP-2 before implantation. All incubations were performed for $3 \mathrm{~h}$ at $37^{\circ} \mathrm{C}$. Matrix from each group was implanted for bio-assay of bone inductive properties: (1) PBS, $7 \mu \mathrm{g}$ BMP-2 $(n=4)$, (2) PBS, $21 \mu \mathrm{g} \mathrm{BMP}-2(n=4)$, (3) GA, $7 \mu \mathrm{g} \mathrm{BMP-2}$ $(n=4)$, and (4) GA, $21 \mu \mathrm{g}$ BMP-2 $(n=4)$. Fourteen days later, the implants were assayed for bone induction.

\section{Materials}

BMP-2 was prepared as previously described [25]. Glycolaldehyde was obtained from Sigma Chemical Co. (St. Louis, Mo., USA) and ${ }^{45} \mathrm{CaCl}_{2}$ from NEN Research Products (Boston, Mass., USA).

\section{Assays}

Fluorescence: Fluorescence of the treated and non-treated bone matrix was measured on a Perkin-Elmer LS-3B spectrofluorometer (Norwalk, Conn., USA). Excitation was at $325 \mathrm{~nm}$ and emission at $400 \mathrm{~nm}[26]$.

${ }^{45}$ Calcium uptake: Fourteen days after implantation, ${ }^{45} \mathrm{CaCl}_{2}$ in $0.9 \%$ saline was injected intraperitoneally at a dose of $1 \mu \mathrm{Ci} / \mathrm{g}$ body weight $2 \mathrm{~h}$ before the rats were killed. The implants were dissected free, weighed, and homogenized in $2 \mathrm{ml}$ ice-cold $0.15 \mathrm{~mol} / 1 \mathrm{NaCl}$ $3 \mathrm{mmol} / \mathrm{NaHCO}$. The specimen was centrifuged for $15 \mathrm{~min}$ at $4^{\circ} \mathrm{C}$ at $20,000 \mathrm{~g}$. The sediment was stirred in $5 \mathrm{ml} 0.1 \mathrm{~mol} / 1 \mathrm{CaCl}_{2}$ in $0.05 \mathrm{~mol} / \mathrm{l}$ Tris- $\mathrm{HCl}$ at $25^{\circ} \mathrm{C}$ for $30 \mathrm{~min}$. It was then centrifuged at $4500 \mathrm{~g}$ for $10 \mathrm{~min}$ and washed twice with $10 \mathrm{ml} 5 \mathrm{mmol} / \mathrm{l}$ Tris- $\mathrm{HCl}$ ( $\mathrm{pH} 7.4$ ). It was centrifuged again at $4500 \mathrm{~g}$ for $5 \mathrm{~min}$, followed by continuous stirring in $10 \mathrm{ml} 0.5 \mathrm{~mol} / 1 \mathrm{HCl}$ for $2 \mathrm{~h}$ at $25^{\circ} \mathrm{C}$. After centrifuging at $4500 \mathrm{~g}$ for $10 \mathrm{~min}$ the sediment was counted.

Alkaline phosphatase: The supernatant from the initial washing with $0.15 \mathrm{~mol} / \mathrm{l} \mathrm{NaCl}$ was assayed for alkaline phosphatase activity [27]. In experiments 1 and 2, the alkaline phosphatase was measured in 100 Sigma units (SU)/g tissue, whereas in experiment 3 it was measured in 100 International units (IU)/g tissue.

Calcium content: The acid soluble fraction of the sediment was assayed for calcium content [28].

Histology: Specimens were fixed in Bouin's fixative for histologic sections. After imbedding, $1 \mu \mathrm{m}$ sections were prepared and stained with haematoxylin and eosin.

\section{Statistical analysis}

All data are expressed as mean \pm SEM. ANOVA and NewmanKuel's tests were used for the statistical analysis. $P$ less than 0.05 was considered significant.

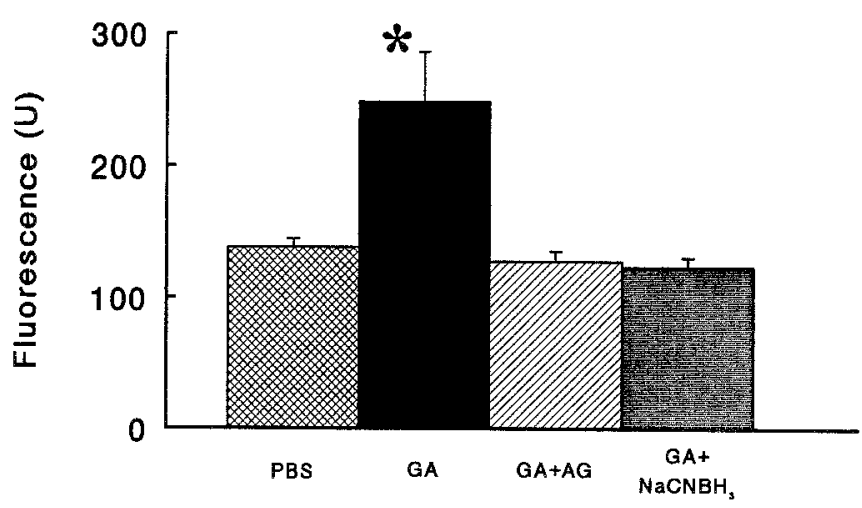

Fig. 1. Fluorescence of matrix according to modes of incubation. Mean \pm SEM; PBS, matrix incubated with phosphate buffered saline; GA, incubation with $50 \mathrm{mmol} / 1$ glycolaldehyde; $G A+A G$, incubation with glycolaldehyde and $250 \mathrm{mmol} / \mathrm{l}$ aminoguanidine$\mathrm{HCl} ; \mathrm{GA}+\mathrm{NaCNBH}_{3}$, incubation with glycolaldehyde and $50 \mathrm{mmol} / \mathrm{l}$ sodium cyanoborohydride. ${ }^{*} p<0.01$ vs other groups 

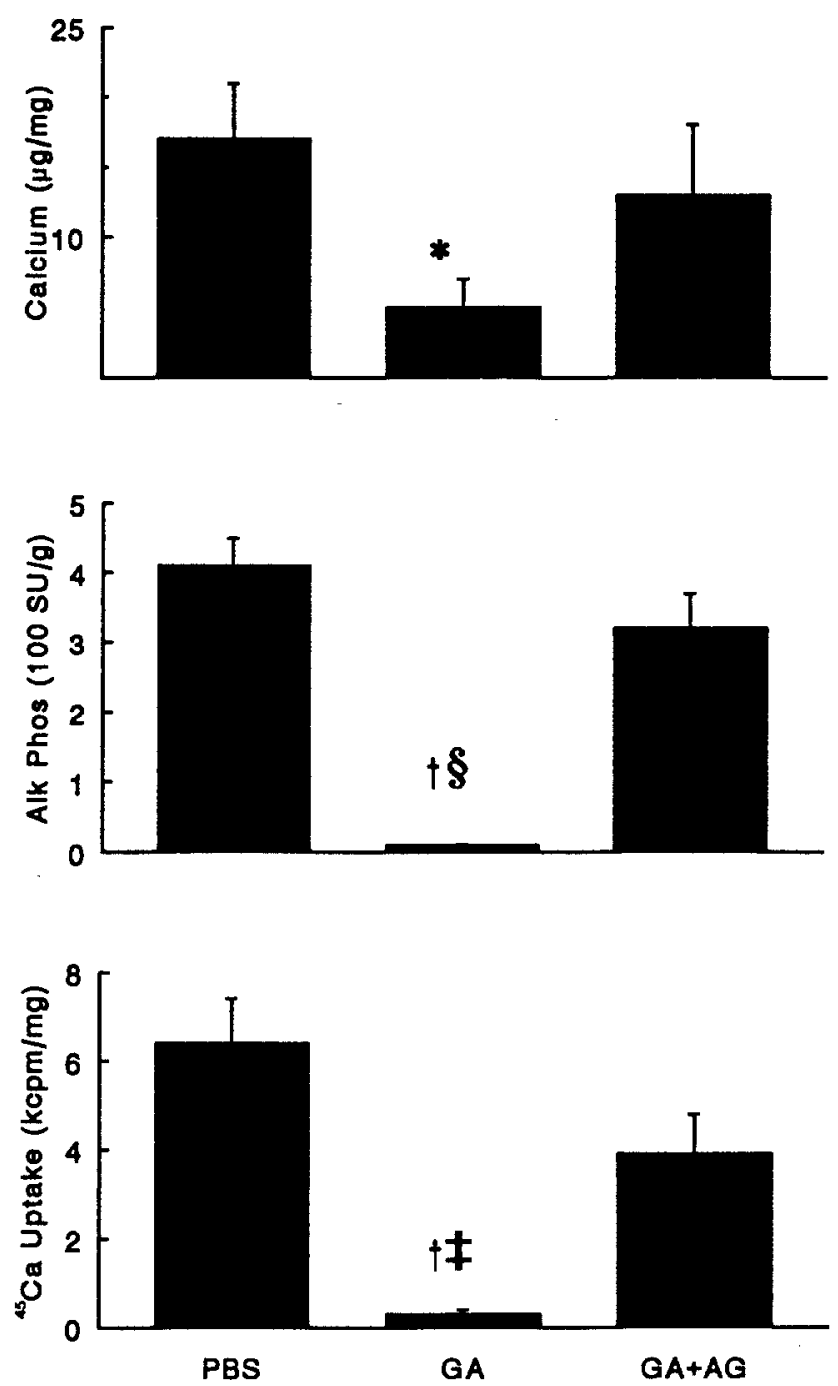

Fig. 2. Effect of glycation and aminoguanidine treatment on matrixinduced bone formation as measured by implant calcium content (calcium), alkaline phosphatase content (Alk phos), and ${ }^{45} \mathrm{Ca}$ uptake. Mean \pm SEM; PBS, matrix incubation with phosphate buffered saline before implantation; GA, incubation with $50 \mathrm{mmol} / \mathrm{l}$ glycolaldehyde; $\mathrm{GA}+\mathrm{AG}$, incubation with glycolaldehyde and $250 \mathrm{mmol} / \mathrm{I}$ aminoguanidine- $\mathrm{HCl}$; implants were harvested 14 days after implantation. ${ }^{*} p<0.05,{ }^{\dagger} p<0.01$ vs $P B S, ; p<0.05,{ }^{8} p<0.01 \mathrm{GA}$ vs $\mathrm{GA}+\mathrm{AG}$

\section{Results}

\section{Experiment 1}

Incubation of the bone matrix with glycolaldehyde increased the amount of AGE products as indicated by increased fluorescence (138 \pm 6 IU, PBS; $248 \pm 38$ IU, GA; $p<0.01$ ) (Fig. 1). In vivo, this corresponded to a significantly reduced ability to induce bone-formation as measured by calcium content $(17 \pm 4 \mu \mathrm{g} / \mathrm{mg}$, PBS; $5 \pm 2 \mu \mathrm{g} / \mathrm{mg}$, GA; $p<0.05$ ), alkaline phosphatase content $(410 \pm 40 \mathrm{SU} / \mathrm{g}, \mathrm{PBS} ; 10 \pm 1 \mathrm{SU} / \mathrm{g}, \mathrm{GA} ; p<0.01)$, and ${ }^{45} \mathrm{Ca}$ uptake $(6.4 \pm 1.0 \mathrm{Kcpm} / \mathrm{mg}$, PBS; $0.3 \pm 0.1 \mathrm{Kcpm} / \mathrm{mg}$, GA; $p<0.01$ ) of the implants (Fig. 2). This reduction in bone induction was also confirmed by histology (Fig. 3).
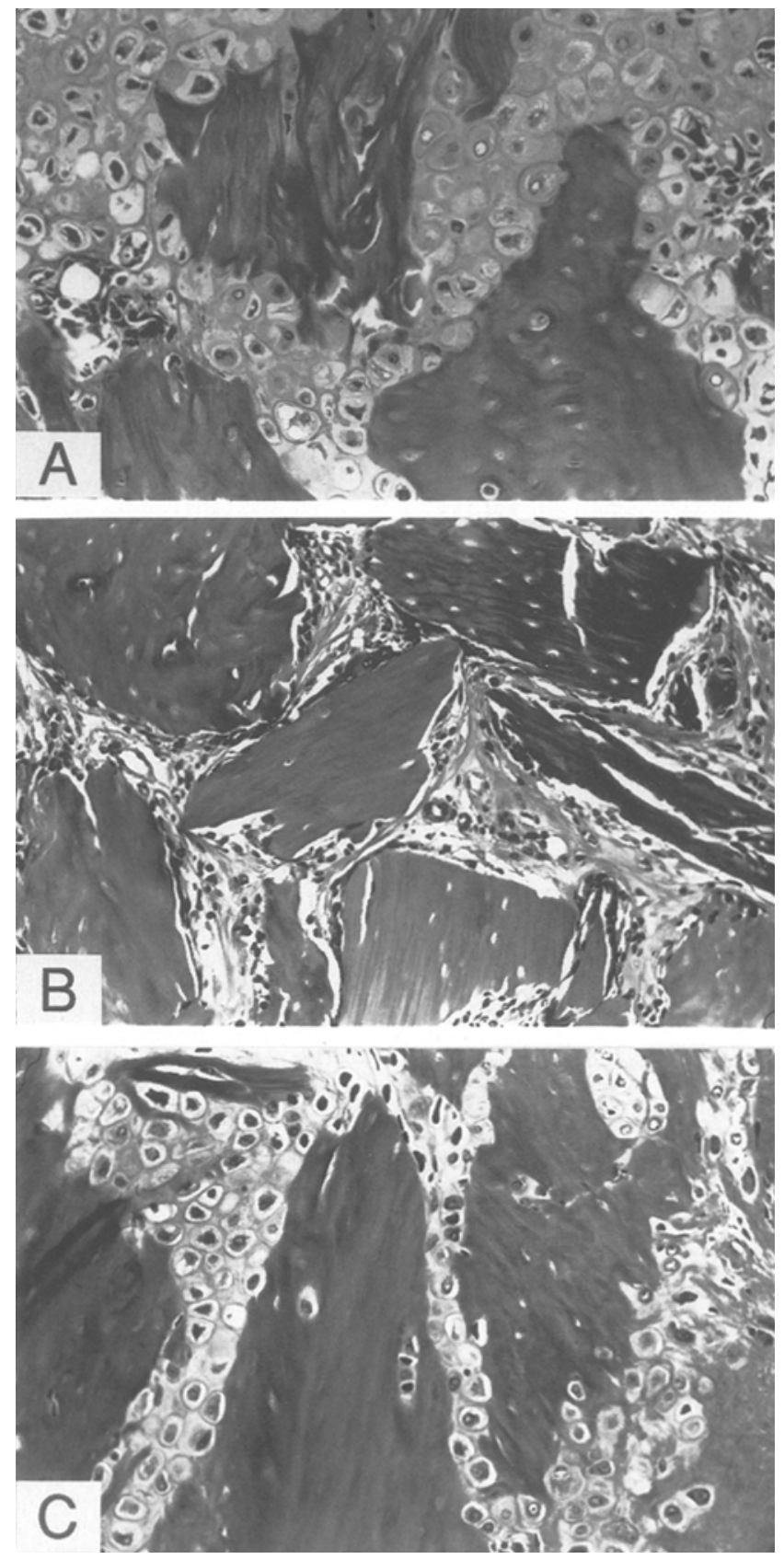

Fig.3A-C. Effects of incubation of bone matrix with glycolaldehyde and aminoguanidine on bone-induction. Photomicrographs demonstrating bone-inductive potential of various preparations of bone matrix. Specimens were removed 14 days after implantation. Haematoxylin and eosin. Magnification $\times 20$. A, control matrix incubated with phosphate buffered saline. Islands of cartilage formation, characterized by lacunae containing chondrocytes, are seen in contact with implanted matrix. B, matrix incubated with $50 \mathrm{mmol} / \mathrm{l}$ glycolaldehyde before implantation. No cartilage or bone elements are noted. C, An implant treated simultaneously with glycolaldehyde and aminoguanidine. Islands of cartilage characterized by lacunae containing chondrocytes are noted

Co-incubation with an inhibitor of AGE formation, aminoguanidine, significantly prevented the effects of glycolaldehyde. Aminoguanidine co-incubated matrix did not have an appreciably different fluorescence pattern than PBS controls (Fig.1). The bone-inductive effects of 
Table 1. Effect of glycation and sodium cyanoborohydride $\left(\mathrm{NaCNBH}_{3}\right)$ treatment of matrix-induced bone formation

\begin{tabular}{lccc}
\hline & $\begin{array}{l}\text { Calcium } \\
(\mu \mathrm{g} / \mathrm{mg})\end{array}$ & $\begin{array}{l}\text { Alkaline } \\
\text { phosphatase } \\
(100 \mathrm{SU} / \mathrm{g})\end{array}$ & $\begin{array}{l}{ }^{45} \mathrm{Ca} \text { uptake } \\
\left(10^{3} \mathrm{cpm} / \mathrm{mg}\right)\end{array}$ \\
\hline $\begin{array}{l}\mathrm{PBS} \\
(n=23)\end{array}$ & $16 \pm 4$ & $5.0 \pm 0.5$ & $6.6 \pm 1.0$ \\
$\begin{array}{l}\mathrm{GA} \\
(n=7)\end{array}$ & $0.6 \pm 0.1^{\mathrm{b} . \mathrm{c}}$ & $0.02 \pm 0.01^{\mathrm{b}, \mathrm{c}}$ & $0.3 \pm 0.2^{\mathrm{b}}$ \\
$\begin{array}{l}\mathrm{GA}+\mathrm{NaCNBH}_{3} \\
(n=12)\end{array}$ & $20 \pm 8$ & $1.5 \pm 0.4^{\mathrm{a}}$ & $1.5 \pm 0.4^{\mathrm{b}}$ \\
\hline
\end{tabular}

Values are given as mean $\pm \mathrm{SEM} ;{ }^{\mathrm{a}} p<0.05$ vs PBS; ${ }^{\mathrm{b}} p<0.01$ vs PBS; ${ }^{c} p<0.05 \mathrm{GA}$ vs GA + $\mathrm{NaCNBH}_{3}$. PBS, Matrix incubation with phosphate buffered saline before implantation; $\mathrm{GA}$, incubation with $50 \mathrm{mmol} / \mathrm{l}$ glycolaldehyde; $\mathrm{GA}+\mathrm{NaCNBH}_{3}$, incubation with glycolaldehyde and $50 \mathrm{mmol} / \mathrm{l}$ sodium cyanoborohydride

matrix incubated with glycolaldehyde and aminoguanidine was not significantly different from the PBS controls as assayed by calcium content, alkaline phosphatase, ${ }^{45}$ Ca uptake (Fig. 2), or histology (Fig. 3).

\section{Experiment 2}

Co-incubation with another inhibitor of AGE formation, $\mathrm{NaCNBH}_{3}$ cyanoborohydride, also significantly prevented the effects of glycolaldehyde. $\mathrm{NaCNBH}_{3} \mathrm{co}$-incubated matrix had a similar fluorescence pattern to PBS controls (Fig. 1). However, in vivo assays demonstrated a partial reduction of bone-inductive capacity of matrix incubated with both glycolaldehyde and $\mathrm{NaCNBH}_{3}$, suggesting that $\mathrm{NaCNBH}_{3}$-stabilized modifications on matrix amino groups also interfered with normal matrixprotein associations (Table 1). This reduction in bone-inductive capacity, as measured by calcium content, alkaline phosphatase ${ }^{45} \mathrm{Ca}$ uptake, or histology of the matrix implants, was not of the same magnitude as that observed after incubation with glycolaldehyde alone.

\section{Experiment 3}

Matrix treated with glycolaldehyde lost the ability to induce bone formation. Application of BMP-2 to glycolaldehyde-treated matrix did not restore the bone inductive capacity of the matrix when measured by alkaline phosphatase levels (Fig.4) or histology (data not shown).

\section{Discussion}

Advanced age and diabetes are each a predisposing factor to bone loss $[1,8,13]$. Proposed mechanisms for these derangements in aging include reduction in calcitonin levels, decreased androgen production, malnutrition, altered calcium absorption, and reduced physical activity [1], whereas in diabetes proposed mechanisms include protein malnutrition, secondary hyperparathyroidism, reduction of sex hormones, increased glucocorticoids, diabetic angio-

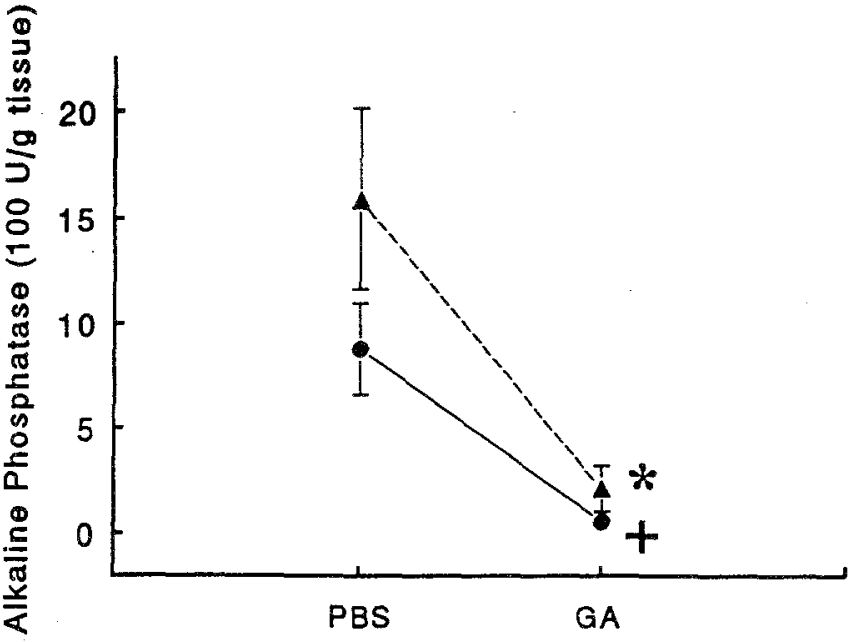

Fig.4. Effect of bone morphogenetic protein 2 (BMP-2) on bone formation by glycated bone matrix as measured by alkaline phosphatase. Bone matrix was incubated in two ways: 1) Phosphate buffered saline (PBS), 2) $50 \mathrm{mmol} / \mathrm{l}$ glycolaldehyde in PBS (GA) were combined with either $7 \mu \mathrm{g}(\boldsymbol{O})$ or $21 \mu \mathrm{g}(\mathbf{A})$ of BMP-2 before implantation. $* p<0.05, * p<0.01$ vs PBS

pathy, deficiency of bone matrix mucopolysaccharide synthesis [13], and effects of insulin deficiency on proliferative mesenchymal cells [23]. While defects in bone metabolism in each case will likely prove multifactorial, we hypothesized that glycation of bone proteins could contribute to these bone derangements. Results in the present study clearly show that modification of bone matrix by glycation alters its ability to induce in vivo bone formation.

Glycation products are formed through slow, nonenzymatic reactions between sugars and proteins. A compound such as glycolaldehyde reacts with amino groups on a protein via nucleophilic addition to form unstable Schiff base adducts, which undergo rearrangement to form Amadori products. The Amadori products may then react with amino groups on another protein to form AGE's, often through covalent cross-links [14, 29, 30]. The AGEs continue to form on long-lived proteins over time and this accumulation is accelerated in diabetes due to chronic hyperglycaemia [31-34]. Obstacles to examining accumulation of AGEs in bone proteins and the biologic effects of such accumulation include the inaccessibility of bone and the prolonged time course of AGE formation. We therefore chose to examine the effects of AGE accumulation in a well-accepted experimental model of bone formation [22-24] using the highly reactive AGE precursor glycolaldehyde [26]. This $\alpha$-hydroxyaldehyde is a glucose-derived compound that undergoes Amadori rearrangements and advanced glycation product formation in a manner similar to glucose. However, since glycolaldehyde is much more reactive than glucose, it forms advanced glycation products within hours instead of weeks to months [26].

In the 1960 s, Huggins and Urist showed that implantation of devitalized and decalcified bone powder in the subcutaneous tissue of animals induced an outgrowth of mesenchymal cells that differentiated into chondrocytes 
[22]. Subsequently, cartilage is replaced by osteoblasts and eventually haematopoietic cells form [35]. The similarity of this sequence to fracture healing has been recognized. The decalcified matrix powder was subsequently shown to be mostly collagen with an amino acid content rich in proline, hydroxyproline, and glycine. In further studies, the matrix has been resolved into extractable and non-extractable fractions [24]. Separation of these fractions results in loss of, and reconstitution restores, the bone-inductive capacities. The extractable portion has also been resolved into a series of growth factors variously called osteogenin and bone morphogenetic proteins [36, 37]. Many of these growth factors have been cloned [37] and seem to have redundant functions since they can independently restore the bone inductive capacity of the non-extractable portion of bone matrix $[37,38]$. It is postulated that these growth factors, in binding to the non-extractable matrix, facilitate mesenchymal cell attachments that lead to bone formation. The observed changes in bone-inductive capacity produced by matrix glycation is most likely due to altered binding of bone associated growth factors since application of recombinant BMP-2 did not restore bone formation. However, an AGE-induced defect in mesenchymal cell binding to the altered matrix may also be responsible.

The current results would seem, at cursory inspection, to be at odds with findings by Landesman and Reddi [39] in a model of experimentally-induced diabetes. These investigators examined the bone-inductive potential of bone matrix from animals with streptozotocin-induced diabetes. In comparisons with bone matrix from control animals, matrix from rats with experimental diabetes of 2 months duration was a superior inducer of bone when assayed on day 11 and equivalent when assayed on day 18 . Though the authors conclude that these findings were related to matrix glycation, no formal quantitation of either early or advanced matrix glycation products was performed. It is unlikely, however, that significant quantities of advanced glycation products had formed in a period as short as 2 months. The complex physiologic alterations associated with diabetes further complicate the interpretation of such in vivo experiments. It is precisely because of these difficulties that we have chosen in the current study to specifically alter bone matrix glycation in vitro.

Certain agents have been shown to block the formation of AGEs. $\mathrm{NaCNBH}_{3}$ selectively reduces reactive Schiff bases, thus stabilizing covalent adducts and inhibiting formation of AGEs [26]. Aminoguanidine inhibits AGE formation primarily by reacting with Amadori-derived intermediates in solution [40]. Aminoguanidine has been shown to dramatically attenuate a number of characteristic diabetic complications in experimental models [41-43]. The current study demonstrates that AGE-inhibition also blocks sugar-induced defects in matrix-induced bone differentiation. Thus, AGE inhibitors, such as aminoguanidine, may have a therapeutic role in the modulation of bone alterations associated with diabetes and aging.

Acknowledgements. This study was supported in part by grants HL32979 and DR33861 from the National Institutes of Health.

\section{References}

1. Francis RM (1990) Osteoporosis: pathogenesis and management. Kluwer Academic Publishers, Boston

2. Herbsman H (1968) Retardation of fracture healing in experimental diabetes. J Surg Res 8: 424-431

3. Herbsman H, Kwon K, Shafton GW, Gordon B, Fox LM, Enquist IF (1966) The influence of systemic factors on fracture healing. J Trauma 6: 75-78

4. Wray JB, Stunkle E (1965) The effect of experimental diabetes upon the breaking strength of healing fracture in the rat. J Surg Res 5: 479-481

5. Cozen L (1972) Does diabetes delay fracture healing · ? Clin Orthop 82: 134-140

6. Lips P, Courpron P, Meuneir PJ (1978) Mean wall thickness of trabecular bone packets in human iliac crest: changes with age. Calcif Tissue Res 26: 13-17

7. Nordin BEC, Aaron J, Speed R, Crilly RG (1981) Bone formation and resorption as the determinants of trabecular bone volume in post-menopausal osteoporosis. Lancet II: 277-279

8. Levin ME, Boisseau VC, Avioli LV (1976) Effects of diabetes mellitus on bone mass in juvenile and adult-onset diabetes. $\mathrm{N}$ Engl J Med 294:241-245

9. Klein J, Frost HM, Sedlin ED (1963) Lamellar bone physiology in diabetes mellitus: mesenchymal cell activation function and haversian canal formation kinetics. Diabetes 12: 362 A (Abstract)

10. Wu K, Schobeck KE, Frost HM, Villaneveva A (1970) Haversian bone formation rates determined by a new method in a mastodon, and in human diabetes mellitus and osteoporosis. Calcif Tissue Res 6: 204-219

11. Benveniste R, Bixler D, Conneally PM (1967) Peridontal disease in diabetics. J Periodontal 38: 271-279

12. Finestone AJ, Boorujy SR (1967) Diabetes mellitus and periodontal disease. Diabetes 16:336-340

13. Fargacs S, Halmos T, Salumon F (1972) Bone changes in diabetes mellitus. Isr J Med Sci 782-783

14. Brownlee M, Vlassara H, Kooney A, Ulrich P, Cerami A (1986) Aminoguanidine prevents diabetes-induced arterial wall protein crosslinking. Science 232:1629-1632

15. Schnider SL, Kohn RR (1981) Effect of age and diabetes mellitus on the solubility and non-enzymatic glycosylation of human skin collagen. J Clin Invest 67: 1630-1635

16. Schnider SL, Kohn RR (1981) Glycosylation of human collagen in aging and diabetes mellitus. $\mathrm{J}$ Clin Invest 67: 1179-1181

17. Tsilbary EC, Charonis AS, Reger LA, Wohlhueter RM, Furtht LT (1988) The effect of nonenzymatic glycosylation on the binding of the main noncollagenous NC1 domain to type IV collagen. J Biol Chem 263: 4302-4308

18. Charonis AS, Reger LA, Dege JE et al. (1990) Laminin alterations after in vitro nonenzymatic glucosylation. Diabetes 39 : $807-814$

19. Tsilibary EC, Charonis AS (1990) The effect of nonenzymatic glucosylation on cell and heparin-binding microdomains from type IV collagen and laminin. Diabetes 39: 194 A (Abstract)

20. Haitglou CS, Tsilibary EC, Brownlee M, Charonis AS (1992) Altered cellular interactions between endothelial cells and nonenzymatically glucosylated laminin/type IV collagen. J Biol Chem 267: 12404-12407

21. Kleinman H, Klebe RJ, Martin GR (1981) Role of collagenous matrices in the adhesion and growth of cells. J Cell Biol 88: $473-485$

22. Urist MR (1965) Bone: formation by autoinduction. Science 150: 893-899

23. Weiss RE, Reddi AH (1980) Influence of experimental diabetes and insulin on matrix-induced cartilage and bone differentiation. Am J Physiol 238: E200-E207

24. Sampath TK, Reddi AH (1981) Dissociative extraction and reconstitution of extracellular matrix components involved in local bone differentiation. Proc Natl Acad Sci USA 78: 7599-7603 
25. Wang EA, Rosen V, D'Alessandro JS et al. (1990) Recombinant human bone morphogenetic protein induces bone formation. Proc Natl Acad Sci USA 87: 2220-2224

26. Acharya AS, Manning IM (1983) Reaction of glycoaldehyde with proteins: latent crosslinking potential of alpha-hydroxyaldehydes. Proc Natl Acad Sci USA 80: 3590-3594

27. Bessey OA, Lowry OH, Brock MJ (1946) A method for the rapid determination of alkaline phosphatase with five cubic millimeters of serum. J Biol Chem 164: 321-329

28. Gitel HJ (1967) An improved automated procedure for the determination of calcium in biochemical specimen. Anal Biochem 18: 521-526

29. Brownlee M (1990) Advanced products of non-enzymatic glycosylation and the pathogenesis of diabetic complications. In: Rifkin H, Porte D (eds) Diabetes mellitus, theory and practice. Elsevier, New York, pp 279-291

30. Higgins PJ, Bunn HF (1981) Kinetic analysis of the nonenzymatic glycosylation of hemoglobin. J Biol Chem 256:5204-5208

31. Brownlee M (1991) Glycosylation products as toxic mediators of diabetic complications. Ann Rev Med 42: 159-166

32. Brownlee M, Cerami A, Vlassara H (1988) Advanced glycosylation end products in tissue and the biochemical basis of diabetic complications. N Engl J Med 318: 1315-1321

33. Monnier VM, Kohn RR, Cerami A (1984) Accelerated age-related browning of human collagen in diabetes mellitus. Proc Natl Acad Sci USA 81: 583-587

34. Araki N, Ueno N, Chakrabarti B, Morino Y, Horiuchi S (1992) Immunochemical evidence for the presence of advanced glycation end products in human lens protein and its positive correlation with aging. J Biol Chem 267: 10211-10214

35. Reddi AH, Anderson WA (1976) Collagenous bone matrix-induced endochondral ossification and hematopoiesis. J Cell Biol 69: $557-572$

36. Carrington JL, Chen P, Yanagishita M, Reddi AH (1991) Osteogenin (bone morphogenetic protein-3) stimulates cartilage formation by chick limb bud cells in vitro. Dev Biol 146: 406-415
37. Wozney JM, Rosen V, Celeste AJ et al. (1988) Novel regulators of bone formation: molecular clones and activities. Science 242: $1528-1534$

38. Muthukumaran N, Ma S, Reddi AH (1988) Dose-dependence of and threshold for optimal bone induction by collagenous bone matrix and osteogenin-enriched fraction. Coll Relat Res 8: 433441

39. Landesman R, Reddi AH (1985) Induction of endochondral bone by demineralized bone matrix from diabetic rats. Calcif Tissue Int 37:630-634

40. Edelstein D, Brownlee M (1992) Mechanistic studies of advanced glycosylation end product inhibition by aminoguanidine. Diabetes 41: 26-29

41. Soules-Liparota T, Cooper M, Papzoglou D, Clarke B, Jerums G (1991) Retardation by aminoguanidine of development of albuminuria mesangial expansion and tissue fluorescence in streptozotocin induced diabetic rat. Diabetes 40: 1328-1335

42. Edelstein D, Brownlee M (1992) Aminoguanidine ameliorates albuminuria in diabetic hypertensive rats. Diabetologia 35: 9697

43. Kihara M, Schmelzer JD, Poduslo JF, Curran GL, Nickander KK, Low PA (1991) Aminoguanidine effects on nerve blood flow, vascular permeability, electrophysiology and oxygen free radicals. Proc Natl Acad Sci USA 88: 6107-6111

Received: 8 February 1993

and in revised form: 3 May 1993

Dr. M. Brownlee

Albert Einstein College of Medicine

1300 Morris Park Avenue

F-531

Bronx, NY 10461

USA 